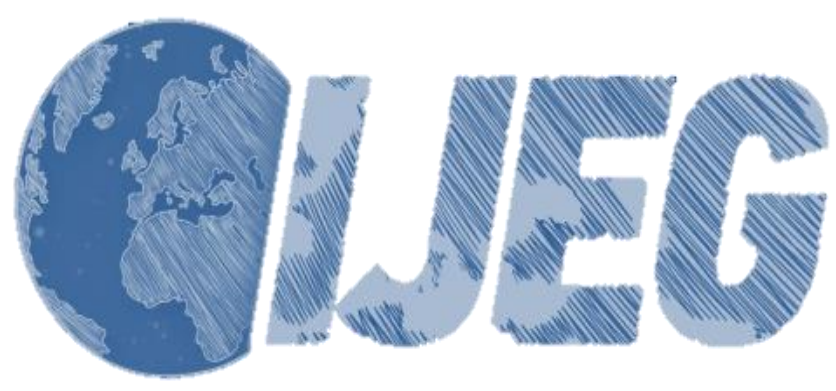

International Journal of Engineering and Geosciences (IJEG), Vol; 4, Issue; 2, pp. 052-057, June, 2019, ISSN 2548-0960, Turkey, DOI: 10.26833 ijeg. 446912

\title{
ANALYZING THE URBANIZATION IN THE PROTECTION AREA OF THE BOSPHORUS
}

\author{
Cigdem Goksel ${ }^{1 *}$, Ahmet Ozgur Dogru ${ }^{1}$ \\ ${ }^{1}$ Istanbul Technical University, Department of Geomatic Engineering, Istanbul, Turkey \\ (goksel@itu.edu.tr ozgur.dogru@itu.edu.tr); ORCID -0000-0001-8480-1435 ; ORCID 0000-0001-7415-1862
}

*Corresponding Author, Received: 23/07/2018, Accepted: 13/08/2018

\begin{abstract}
Istanbul, being one of the oldest and crowded cities in the world bridging the Asia and Europe continents, is ranked as the $15^{\text {th }}$ populated mega city among the 75 largest metropolitans in the world as a result of the rapid population growth since the year of 1950. The stated growth caused a significant need for housing, therefore new settlements have been built in and around the city threating water resources, protected areas, and sensitive lands such as agricultural areas, forests, wetlands in the city. As a result of these adverse developments, the Bosphorus zone, which has a historical and geographical importance for Istanbul, was declared as a protected zone for stopping the threat of unplanned urbanization along the Bosphorus. The Bosphorus area were divided in to two protection zones as Back View and Front View Zones by the laws in terms of the stated protection plan. The main goal of this study is to examine the changes in settlement areas in the protected zones of Bosphorus specifically in Sariyer District. In this context, Landsat imageries dated 2005 and 2017 were used to determine the urban sprawl during 12 years in the protection zone of Bosphorus. The results of the study introduced $10 \%$ decrease in the forest and green lands from 2005 to 2017 while $8 \%$ and $11 \%$ increase in settlements and the other land use classes respectively. In order to perform more detailed analyses of this change, a detailed study was performed for Front and Back View Zones of Bosphorus in Sariyer district using 2005 and 2017 dated IKONOS satellite images. The map of Sariyer district produced in 1960 was considered as the reference data source as well as image for detecting the changes in the study area during 57 years in two periods. The results of the study outlined that the settlements in the study area increased $173 \%$ and $142 \%$ for two periods from 1960 to 2005 and from 2005 to 2017 respectively. The increase in settlement areas caused a decrease in forests and green lands in the study area. In particular, the study introduced the illegal settlement area increase in the protection zones of the Bosphorus based on the Bosphorus Law No. 2960 in Sariyer District.
\end{abstract}

Keywords: Remote Sensing, Change Detection, Urbanization, Urban Sprawl 


\section{INTRODUCTION}

Istanbul Strait, in other words the Bosphorus, is a unique territory with its topographic features, historical characteristics, green spaces, living coastline, architectural features and urban texture and it should be extensively protected by regulations and law. The Bosphorus has maintained its importance as a settlement area throughout history and it has also provided a living space for inhabitants with surrounding plantations. Therefore, organizations responsible for the urban planning have considered the protection of the natural and cultural heritage at Bosphorus area while providing development plans of the area since 1970s. However, these attempts have not fully succeeded as a result of grooving population mostly caused by internal migration, inconsistencies in plans and protection orders or interventions of the political actors. Consequently, the Bosphorus have been under the threat of legal or illegal urbanization and industrialization for many years.

As a precaution, the Bosphorus Law No. 2960 came in to force on 18th November 1983 for the governance of the rapid urbanization at the Bosphorus area. According to the law, the Bosphorus area were divided in to four parts as water side, Front View, Back View and Effect Zones as presented in Figure 1. The Bosphorus area was considered as recreation, tourism and settlement area with this law and decided to be legally protected with its existing natural and historical characteristics (Gülersoy and Selçuk, 1993; Kap, 2008). However, an urban design guide was prepared for an area including private owned green areas with construction permissions and this guide was confirmed by the cultural and natural heritage preservation board (Gülersoy, 1995; Gökçek, 1992; IBB, 2007). These prevention attempts were interrupted by Development Plan Law Num. 3194 which was enacted in 1985 after the inurement of the Bosphorus Law since it legislated all previous illegal acts and opened some areas in the protection zone for settlement. Therefore, the period after the year 1985 was considered as rapid urbanization period of the Bosphorus area (Örmeci et al., 1996).

The first goal of this study is to determine the land use / land cover (LU/LC) changes in especially settlement and green areas in the protection area of the Bosphorus for last 12 years from 2005 to 2017 by processing and analysing Landsat TM and ETM images. Additionally, this study aims to detect the changes in Kirecburnu and Buyukdere neighbourhoods located at a part of Front View and Back View Zones of the Bosphorus in Sariyer where urbanization highly effected for years. For this purpose, 2005 and 2017 dated IKONOS imagery data with $1 \mathrm{~m}$ spatial resolution were used in order to obtain more accurate results. The changes in urban and green areas were analysed based on 1:5000 scaled topographic maps of Istanbul dated 1960 in the second part of the study.

\section{STUDY AREA}

The Bosphorus preservation areas have a significant importance a natural and cultural heritage of Istanbul. This region included Sariyer and Beşiktaş districts in European side and Beykoz and Uskudar districts in Asian side of Istanbul. The area has been threatened by unplanned and illegal urbanization since 1950s. According to the Bosphorus Law No. 2960, the
Bosphorus was divided in to four main regions as coastal line, Front View Zone, Back View Zone and Effect Zone. Front View Zone of the Bosphorus included most important preservation areas and it covered an area of 4300 ha, while Back View Zone covered an area of 1000 ha located between Front View Zone and Effect Zone which formed border zone of 5300 ha between the urban and rural areas of Istanbul when the Bosphorus Law enacted. Figure 1 presents the extended study area borders as the Front View and Back View Zones at the Bosphorus. The study mainly focused on the Front View and Back View Zones at Sariyer District.

\section{METHODOLOGY AND DATA PROCESSING}

Satellite remote sensing is a potentially powerful means of monitoring land-use change at high temporal resolution and economic than those associated with the use of traditional methods (El-Raey et al., 1995).

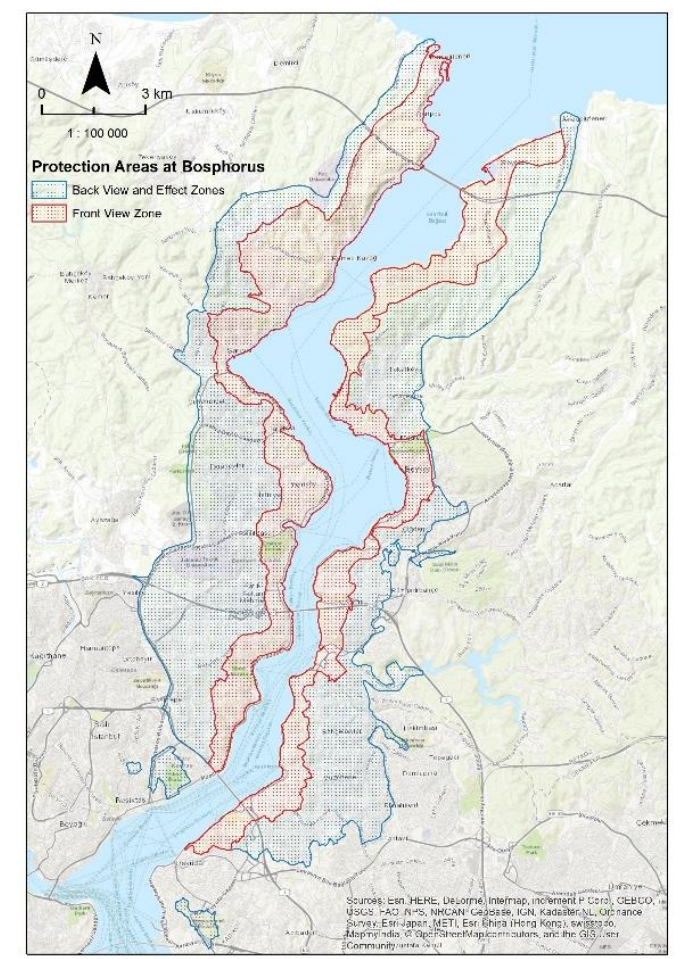

Figure 1. Front View, Back View and Effect Zones at the Bosphorus (adapted from Vural, E. 2008)

Digital change detection is the process of determining and/or describing changes in LU/LC properties based on co-registered multi-temporal remote sensing data. The basic premise in using remote sensing data for change detection is that the process can identify change between two or more different dates. Numerous researchers have addressed the problem of monitoring LU/LC change (Yuan et al., 2005; Bektas and Goksel, 2005, Dogru et al., 2009; Belal, and Moghanm, 2011).

In this study Landsat TM (2005), Landsat 8 OLI (2017) and IKONOS images were used as the geometric data as well as 1:5000 scaled topographic map sheet covering some part of the Sariyer District which was 
produced in 1960 and used as the basic reference data for introducing LU/LC change in 57 years. ERDAS Imagine 9.2 software were used for processing remote sensing imageries. Digitization and the georeferencing of the topographic map and visualization of the results as final map were succeeded using ArcMap 10.6.

Satellite data used in the study were processed at four main stages as: geometric correction of remotely sensed images and maps as data pre-processing, classification of the satellite images together with its accuracy assessment and digitization.

\subsection{Geometric Correction of Satellite Images}

As the first step of the geometric correction high resolution IKONOS satellite images used this study were geometrically referenced to a common coordinate system defined in a projection. For this purpose, 1:5000 scaled orthophoto maps were used as reference data and ground control points were rigorously selected as homogenously distributed on the image. As a result of this process 2005 and 2017 dated IKONOS images were georeferenced to Universal Transverse Mercator (UTM) projection based on the World Geodetic System 1984 (WGS 84) datum. International ellipsoid 1909 was selected as reference ellipsoid of the data. Nearest Neighbour Interpolation were applied at the resampling stage for ensuring a minimum change in spectral values of the images. This process was completed with a root mean square error (RMSE) of \pm 0.5 pixel for both images. Additionally, 2005 and 2017 dated Landsat images used in the study were geometrically corrected using 15 ground control points for each based on 2005 dated IKONOS image with 0.5 pixel RMSE.

\subsection{Geometric Correction of Maps}

The study aims at the integration of the information derived from existing analogue maps with remote sensing data defined at a common coordinate system for providing more detailed interpretation of the results. In this context, two 1:5000 scaled analogue maps dated 1960 was first scanned and then georeferenced using Geographic Information System (GIS) technology within this study. For this purpose, maps in raster format were transformed in to UTM projection system using polynomial transformation methodology (Lillesand and Kiefer, 2001). A number of graphical elements of spatial objects were identified and selected as control points and check points on each data. Ground control point (GCP) selection process included two important problems (Goksel et al., 2016). Firstly, it was difficult to find out the GCP because of the change at the field occurred in 45 years' period from 1960 to 2005 . Secondly, the GCP was not selected on the homogeneous distribution in the area. As a result, geometrical correction of the raster maps was performed using 6 GCP with 0.4 pixel RMSE.

\subsection{Classification and Accuracy Assessment}

Image classification techniques are widely used in determining land use and land cover changes (Goksel, et al., 2018; Karakuş, et al., 2017). In this study, Landsat images with $30 \mathrm{~m}$ spatial resolution used for determining LU/LC characteristics of Bosphorus protection zone in 2005 and 2017. For this purpose; Maximum likelihood supervised classification methodology was applied in order to map main LU/LC characteristics of the study area as (i) green lands and forests (ii) settlement- urban built up and roads and (iii) others. The change in between the years was also calculated after completing classification process. The error matrix and Kappa methods were used to assess the thematic mapping accuracy. Accuracy assessment of the LU/LC classification succeeded with $87 \%$ and $81 \%$ overall accuracies for 2005 and 2017 dated Landsat data respectively. The Kappa coefficients for 2005 and 2017 maps were also obtained as 0.803 and 0.745 respectively.

\subsection{Digitization}

In order to determine the areal change in settlement area based on building area in Sariyer district, most of the buildings located at Sariyer Center, Tarabya and Camlitepe neighbourhoods and all of the buildings located at Kazim Karabekir, PTT Evleri, Maden, Kocatas, Buyukdere, Cayirbasi, Cumhuriyet, Kirecburnu neighbourhoods were manually digitized from both raster maps and high resolution IKONOS images. After completing the digitization of the settlement data changes in settlement are in Sariyer District were determined (Goksel et al. 2016).

\section{RESULTS}

Results of the study are obtained in two different scopes: firstly, general overview of the LU/LC changes in Bosphorus Protection Zone and secondly detailed examination of the Sariyer District. LU/LC classification results of the Bosphorus protection Zone is visualized as LU/LC maps of the study area in Figure 2. The numeric results were also presented in Table 1 by grouping four LU/LC classes in to three classes as Forest and Green Areas, Settlements-Urban Builtup \& Roads and Others. As presented in the table, while Forest and Green Areas in Bosphorus Protection Zone decreased 526.5 ha with a $-10.1 \%$ rate in 12 years Settlements and Roads increased 449.5 ha. This result confirms the illegal urbanization at the Bosphorus protected by laws. 

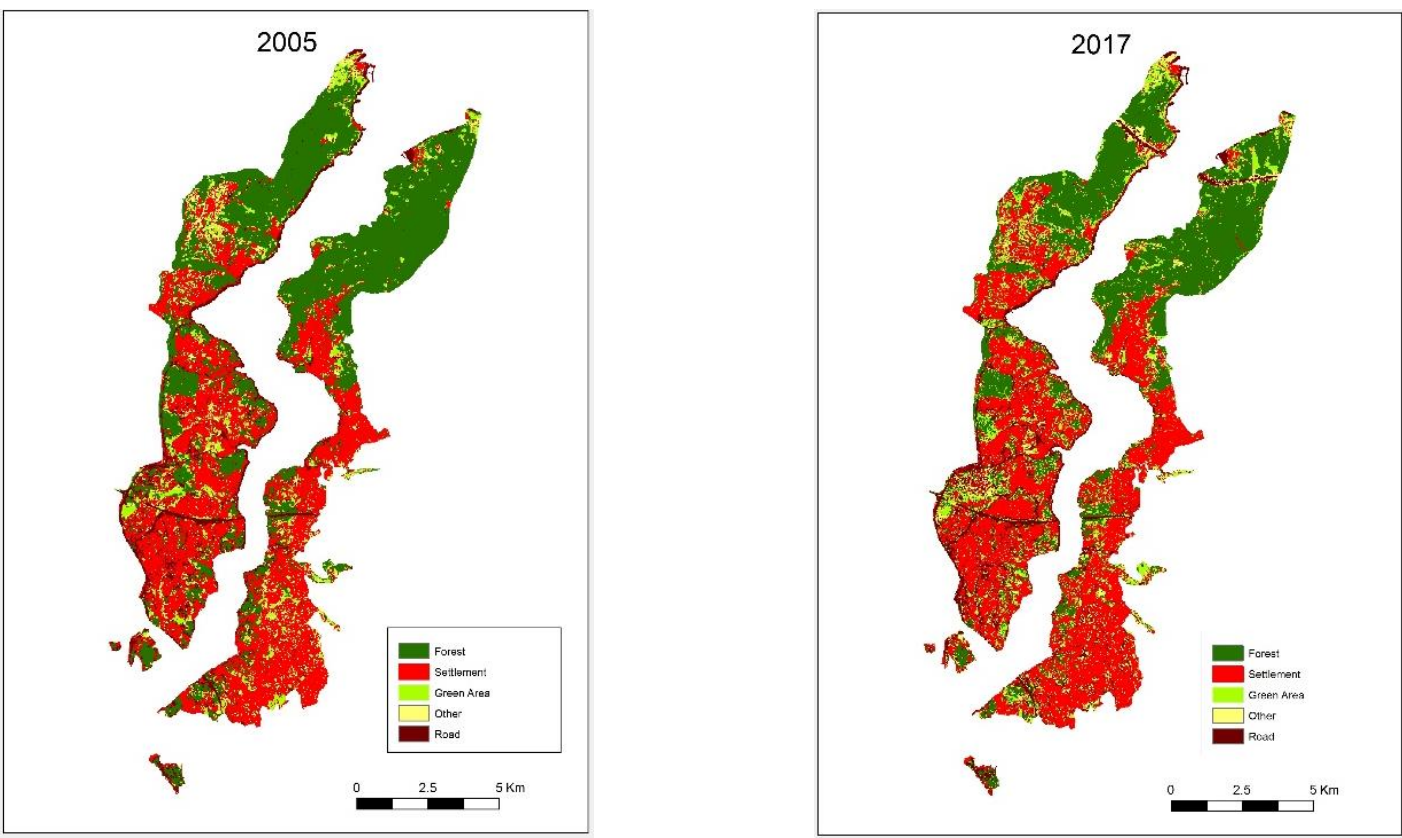

Figure 2. 2005 and 2017 dated LU/LC maps of the Bosphorus Protection Zones

Table 1. Areas of LU/LC classes and change in 12 years in Bosphorus Protection Zone

\begin{tabular}{lcccccc}
\hline \multirow{2}{*}{ LU/LC Class } & \multicolumn{2}{c}{2005} & \multicolumn{2}{c}{2017} & \multicolumn{2}{c}{ Change } \\
\cline { 2 - 6 } & ha & $\%$ in study area & ha & $\%$ in study area & ha & $\%$ \\
\hline $\begin{array}{l}\text { Forest and } \\
\text { Green Areas }\end{array}$ & 5229.1 & 46.1 & 4702.6 & 41.5 & -526.5 & -10.1 \\
$\begin{array}{l}\text { Settlements and } \\
\text { Roads }\end{array}$ & 5414.4 & 47.7 & 5863.4 & 51.7 & 449.0 & 8.3 \\
Others & 698.0 & 6.2 & 775.5 & 6.8 & 77.5 & 11.1 \\
\hline Total & 11341.5 & & 11341.5 & & & \\
\hline
\end{tabular}

Results of the examination of the urbanization processes in Sariyer District were presented in Figure 3 and Table 2. Map in the Figure 3 presents the digitization results of building areas in 1960, 2005 and 2017 in three different colures. A numerical comparison of the building areas in 1960, 2005 and 2017 were also presented in Table 2. As presented in the table building areas in located at the Back View and Front View Zone in the study area increased with rates of $173 \%$ and $142 \%$ in two study periods. Total increase rate in settlement areas from 1960 to 2017 was determined as $420 \%$ from 15 ha to 78 ha.
Table 2. Comparison of settlement areas

\begin{tabular}{ccc|c}
\hline Years & $\begin{array}{c}\text { Settlement Area } \\
\text { by Year (ha) }\end{array}$ & $\begin{array}{c}\text { Total Settlement } \\
\text { Area (ha) }\end{array}$ & $\begin{array}{c}\text { Increase } \\
\text { Rate (\%) }\end{array}$ \\
\hline 1960 & 15 & 15 & \multirow{2}{*}{173} \\
\cline { 1 - 2 } 2005 & 26 & 41 & \multirow{2}{*}{142} \\
\hline 2017 & 37 & 78 & \\
\hline
\end{tabular}




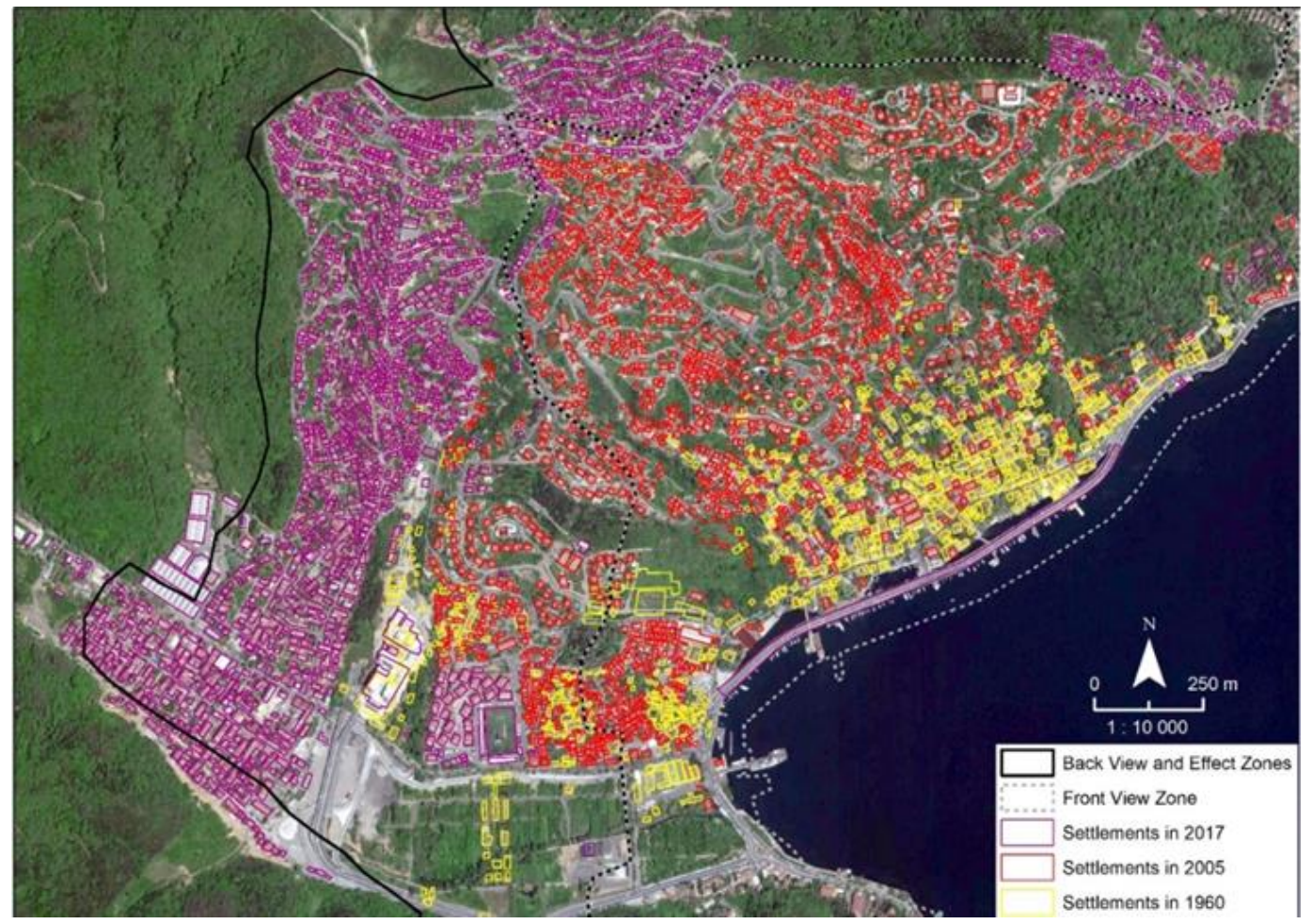

Figure 3. Building areas in three different years

\section{CONCLUSION}

This study confirms the usability of the data sets from different sources and formats in studies performed for detecting the LC/LU change. A wide variety of maps as urban development plans or topographic maps in analogue or digital formats and produced using traditional or current mapping methodologies, as remote sensing or aerial photography, can be efficiently used in change detection. The main requirement for the success of such data uses is to define and structure the all geometric data at a common geographic reference system. In this study, many challenges of georeferencing, map matching and digitizing processes mainly originated by the deformations on paper maps were succeeded.

As a result of the change detection process, it is concluded that the green areas and forests in the preservation area of the Bosphorus were significantly damaged in 12 years' time from 2005 to 2017 . These results indicated the increase in settlement areas (8.3\%) replaced with forests and green areas. Building area increased with $223 \%$ in 45 years' time from 1960 to 2005 also confirms this result. The census statistics of TUIK presents more than $450 \%$ increase in Sariyer's population at the same period (URL 1) and this result indicated the increase in the number of multi-storey building in the study area. Consequently, determined change is the exact indicator of the difficulties in application of the laws and legislation as the Bosphorus Law, Bosphorus development plans and etc. on preservation of the economically and culturally most valuable area in Istanbul.

\section{REFERENCES}

Bektas, F., and Goksel, C. (2005). Remote Sensing And GIS Integration For Land Cover Analysis, A Case Study: Bozcaada Island. Water Science and Technology, 51(11), 239-244.

Belal, A.A., Moghanm, F.S. (2011). Detecting Urban Growth Using Remote Sensing And GIS Techniques In Al Gharbiya Governotare, Egypt. The Egyptian Journal of Remote Sensing and Space Sciences, 14, 73-79.

Dogru, A.O., Balcik, F., Sanli, F., Goksel, C., Ulugtekin, N. (2009). A Change Detection Analysis in the Izmir Bird Paradise: Integration of Remote Sensing and Geographic Information System. Fresenius Environmental Bulletin (FEB), Vol 18, No 1, pp. $51-56$,

EL-RAEY, M., Nasr, S. M., El-Hattab, M. M., \& Frihy, O. E. (1995). Change detection of Rosetta promontory over the last forty years. Remote Sensing, 16(5), 825-834.

Gökçek, G. (1992). Boğaziçi Plan Kararlarının İrdelenmesi ve $\mathrm{Bu}$ Kararların Yap1, Doku ve Silüet ile İlişkilenmesi Sariyer Örneği, Master Thesis, MSÜ Institute of Science and Technology.

Goksel, C., Dogru A. O. and Vural, E. (2016) “Analyzing The Urbanization In The Forescene And Backscene Zone Of The Bosphorus In Sariyer District". Proceedings, Selçuk International Scientific Conference On Applied Sciences, 27-30 September 2016, Antalya-Turkey 
Gülersoy, N,Z. (1995). Boğaziçi'nde Arazi Kullanımı ve Ulasım, Istanbul Dergisi, No: 14, Tarih Vakfi, pp.59-63.

Gülersoy,N.Z., Selçuk, Z. (1993) "Istanbul Boğaziçi Koruma Alanında 1970-1990 Y1lları Arasındaki Gelişmelerin Değerlendirilmesi”. Türkiye'de 17. Dünya Şehircilik Günü Kolokyumu Bildiriler Kitabı. pp. 345-362.

IBB, 2007, Istanbul Metropolitan Municipality Strategic Plan for 2002-2011 period, available at: http://www.sp.gov.tr/upload/xSPStratejikPlan/files/2dW VM+IstanbulBuyuksehirSP20072011.pdf, last accessed on 14.08.2016.

Kap, S.D. (2008). "The Effect of the Legal Arrangements on the Istanbul Bosphorus Landscape Areas and European Landscape Convention as an Opportunity for Restructuring". Proceeding of 1st WSEAS International Conference on Landscape Architecture (LA '08), Algarve, Portugal, June 11-13, 2008. Pp.183-188

Göksel, Ç., David, R.M. and Dogru, A. O.(2018) "Environmental Monitoring of Spatio-Temporal Changes in Northern Istanbul using Remote Sensing and GIS". International Journal of Environment and Geoinformatics 5(1): 94-103 (2018)

Karakus, P., Karabork, H., \& Kaya, S. (2017). A Comparison Of The Classification Accuracies In
Determining The Land Cover Of Kadirli Region Of Turkey By Using The Pixel Based And Object Based Classification Algorithms. International Journal of Engineering and Geosciences (IJEG), 2, 52-60.

Lillesand, T.M. and Kiefer, R.W. (2001). Remote Sensing and Image Interpretation, John-Wiley and Sons., New York.

Örmeci, C. Türkoğlu, H. and Göksel, Ç., (1996). "Uzaktan Algılama Yöntemi Kullanılarak İstanbul Boğaziçi'nde Arazi Kullanımındaki Değişimin Analizi”. Proceeding of Istanbul 2020 Syposium-İTÜ, April 1996, pp:265-273.

URL 1: https://biruni.tuik.gov.tr, Official website of the Turkish Statistical Institute Data/Information Portal, last accessed on 14.08.2016.

Vural, E. (2008). Boğaziçi SİT Alanındaki Arazi Kullanımının Zamansal Değerlendirmesi, Master Thesis, ITÜ Graduate School of Science Technology and Engineering.

Yuan, F., Sawaya, K.E., Loeffelholz, B.C., Bauer, M.E., (2005). Land cover classification and change analysis of the twin cities (Minnesota) metropolitan area by multitemporal Landsat remote sensing. Remote Sensing of Environment. 98, 317-328. 